\title{
Prediction and Monitoring of Deformation of Supporting Structure during Excavation of Super-large Foundation Pits
}

\author{
Xiao-Qin WANG ${ }^{1}$, Ting-Ting SUN ${ }^{2}$, Peng-Tao $\mathrm{HU}^{3}$ \\ ${ }^{1}$ The Department of Urban Construction, City College, Wuhan University of Science and \\ Technology, Wuhan 430083, Hubei \\ ${ }^{2}$ The Department of Architectural Engineering, Anqing Vocational \& Technical College, Anqing \\ 246003, Anhui \\ ${ }^{3}$ Hubei Runke Construction Group Co., Ltd. Wuhan 430083, Hubei \\ 79258706@qq.com
}

Keywords: Super-large Foundation Pit, Supporting Structure, Deformation, Prediction, Monitoring.

\begin{abstract}
With the construction of the super-large foundation pit for Wuhan metro as the engineering background, this study predicted the deformation of supporting structure and the distribution of earth pressure in the active zone at different stages of step-by-step excavation and analyzed the "soil arching effect" and the fragile parts of the foundation pit during excavation by comparing the predicted and monitored data.
\end{abstract}

\section{Introduction}

The step-by-step excavation of foundation pits is a complex interaction of dynamic soil and supporting structure, and the conventional vertical beam on-elastic-foundation method cannot solve the problem of predicting the deformation of foundation pits. On the basis of the three-dimensional numerical analysis of continuum mechanics, this paper considered the interaction between the supporting structure for the foundation pit and soil and simulated the deformation characteristics of soil and the supporting structure during excavation of the super-large foundation pit for Wuhan metro.

\section{Engineering Background}
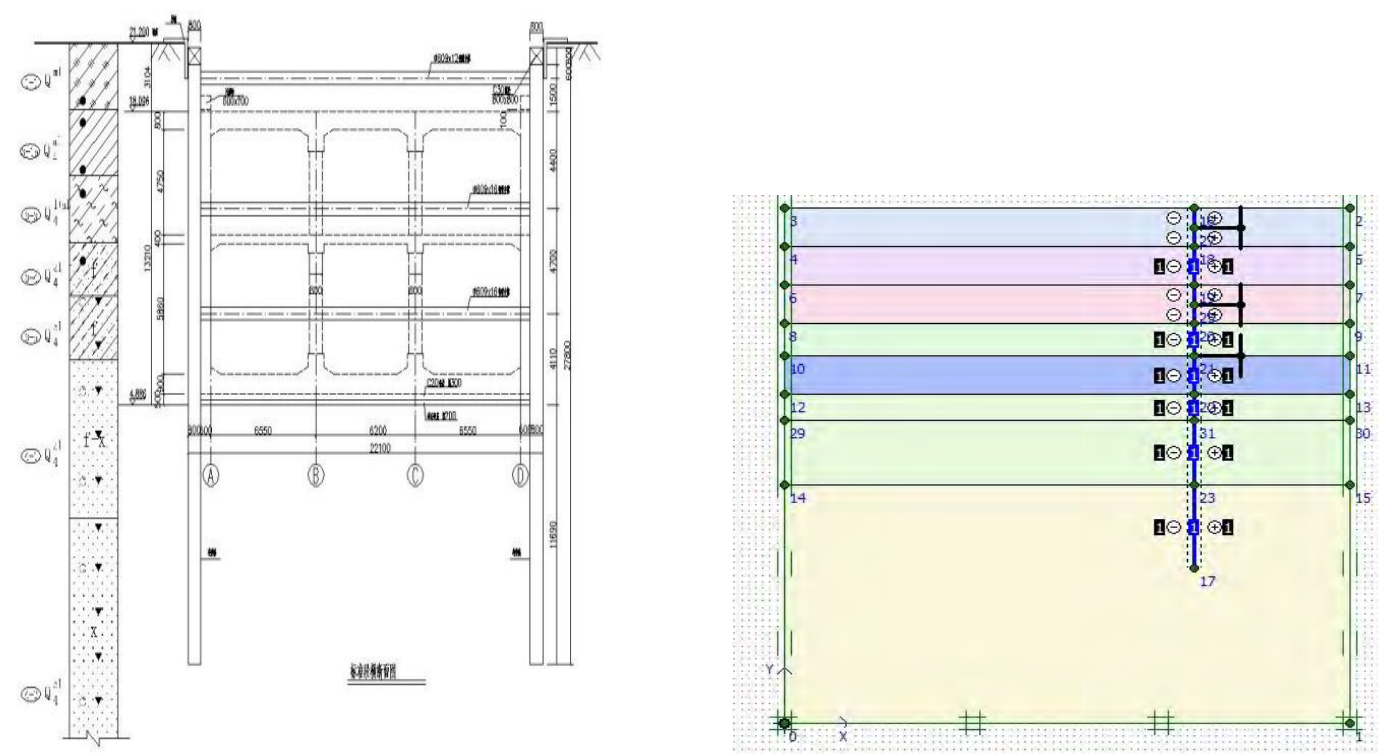

Fig. 1 Cross Section Drawing of the Standard Section

Fig. 2 Geometric Model

The depth of excavation of the foundation pit for the main end well of this station was about 17.4 $\mathrm{m}$, the depth of excavation of the standard section of the foundation pit was about $16.21 \mathrm{~m}$, and the 
depth of excavation of the transfer station with Line 3 was about $24.61 \mathrm{~m}$. The bottom of the foundation pit was in the (3-4) layer of silty clay. The toe of the diaphragm wall went no less than 2 $\mathrm{m}$ deep into the (20a-1) layer of highly weathered mudstone and the (20a-2) layer of moderately weathered mudstone. $800 \mathrm{~mm}$ thick (1000 $\mathrm{m}$ thick at the transfer station nodes) diaphragm wall and $\varphi 609$ steel support were used to support and retain the foundation pit, with horizontal spacing of 2.5 $\mathrm{m}$ between the supports and slight adjustments in local spacing. Four supports were vertically installed for the shield shaft and the south end, six supports were installed for the foundation pit of the transfer station nodes (the fourth and fifth supports needed to be replaced), and three supports were vertically installed for the standard section of the foundation pit and others. Reinforced concrete whole plane truss was installed inside the top beam plane of the irregular foundation pit at the south end, as shown in Figure 1.

\section{Numerical Simulation of the Foundation Pit}

This paper studied the excavation of the standard section of the foundation pit and numerically simulated the changes in soil layers during excavation. The depth of excavation was $16.5 \mathrm{~m}$, and the depth of the diaphragm wall was $28 \mathrm{~m}$. There were seven soil layers in total, and the thicknesses of the first to sixth soil layers were $3000 \mathrm{~mm}, 3000 \mathrm{~mm}, 3000 \mathrm{~mm}, 2500 \mathrm{~mm}, 3000 \mathrm{~mm}$, and $7000 \mathrm{~mm}$, respectively (rounded). The geometric model is shown in Figure 2. The concrete parameters for the soil layers are shown in Table 1.

The excavation process in this paper was simulated as six construction steps. The curve for the soil displacement for a depth of excavation of $16.5 \mathrm{~m}$ is shown in Figure 3.

Tab. 1 Values of the Parameters for the Soil Layers

\begin{tabular}{|c|c|c|c|c|c|c|}
\hline \multirow{2}{*}{$\begin{array}{l}\text { Stratu } \\
\text { m No. }\end{array}$} & \multirow[b]{2}{*}{ Stratum name } & \multirow{2}{*}{$\begin{array}{c}\text { Liquidity } \\
\text { index } \\
I_{L}\end{array}$} & \multirow{2}{*}{$\begin{array}{c}\text { Natural } \\
\text { specific } \\
\text { weight } \\
\mathrm{KN} / \mathrm{m}\end{array}$} & \multicolumn{2}{|c|}{ Suggested value } & \multirow{2}{*}{$\begin{array}{c}\text { The } \\
\text { coefficient } \\
\text { of static } \\
\text { lateral } \\
\text { pressure }\end{array}$} \\
\hline & & & & $\mathrm{C}_{K P_{a}}$ & $\varnothing$ degree & \\
\hline$(1-1)$ & $\begin{array}{l}\text { miscellaneous } \\
\text { fill }\end{array}$ & & 17.5 & 5.0 & 18.0 & 0.60 \\
\hline$(1-2)$ & $\begin{array}{l}\text { miscellaneous } \\
\text { fill }\end{array}$ & & 17.8 & 8.0 & 10.0 & 0.60 \\
\hline$(1-3)$ & silt & & 16.5 & 6.0 & 3.5 & 0.75 \\
\hline$(3-1)$ & clay & 0.74 & 18.1 & 17.0 & 10.0 & 0.55 \\
\hline$(3-3)$ & $\begin{array}{l}\text { muddy silty } \\
\text { clay }\end{array}$ & 1.11 & 17.6 & 12.0 & 6.0 & 0.65 \\
\hline$(3-4)$ & silty clay & 0.96 & 17.6 & 15.0 & 10.0 & 0.60 \\
\hline$(3-5)$ & silty clay & 1.06 & 17.7 & 10.0 & 20.0 & 0.59 \\
\hline$(4-1)$ & $\begin{array}{l}\text { Silty fine } \\
\text { sand }\end{array}$ & & 19.0 & 0.0 & 33.0 & 0.42 \\
\hline$(4-2 a)$ & fine sand & & 19.4 & 0.0 & 37.0 & 0.38 \\
\hline$(4-2)$ & silty clay & 0.48 & 18.7 & 25.0 & 13.0 & 0.49 \\
\hline$(4-3)$ & $\begin{array}{c}\text { Medium } \\
\text { coarse sand }\end{array}$ & & 20.0 & & & \\
\hline$(20 a-1)$ & Mudstone & & 25.5 & & & \\
\hline$(20 a-3)$ & Mudstone & & 25.6 & & 30.4 & \\
\hline
\end{tabular}


Tab. 2 Predicted Values of the Maximum Displacements of Soil before and after Supporting after Excavation

\begin{tabular}{cccccc}
\hline $\begin{array}{c}\text { Constructi } \\
\text { on step }\end{array}$ & $\begin{array}{c}\text { Depth of } \\
\text { excavation } \\
(\mathrm{m})\end{array}$ & $\begin{array}{c}\text { Maximum } \\
\text { displacement }(\mathrm{mm}) \\
\text { Predicte } \\
\text { d value }\end{array}$ & $\begin{array}{c}\text { Measure } \\
\text { d value }\end{array}$ & $\begin{array}{c}\text { Location for maximum } \\
\text { Predicted } \\
\text { value }\end{array}$ & $\begin{array}{c}\text { Measured } \\
\text { value }\end{array}$ \\
\hline Before & 3 & 5.7 & 7.2 & $(31.86,37)$ & $(32,36.8)$ \\
supportin & 9 & 12.6 & 15.0 & $(30.13,31)$ & $(30.0,31)$ \\
g & 11.5 & 0.9 & 2.0 & $(30.13,28,5)$ & $(30.5,28.3)$ \\
After & 3 & 0.01 & 0.1 & $(33.37,37)$ & $(33.6,37.6)$ \\
supportin & 9 & 0.2 & 1.0 & $(29,29.75)$ & $(29.0,29.7)$ \\
g & 11.5 & 0.00 & 0.09 & $(31.41,25.8)$ & $(31.2,27.0)$ \\
& 16.5 & 1.5 & 1.9 & $(29.377,23.5)$ & $(29.0,23.1)$ \\
\hline
\end{tabular}

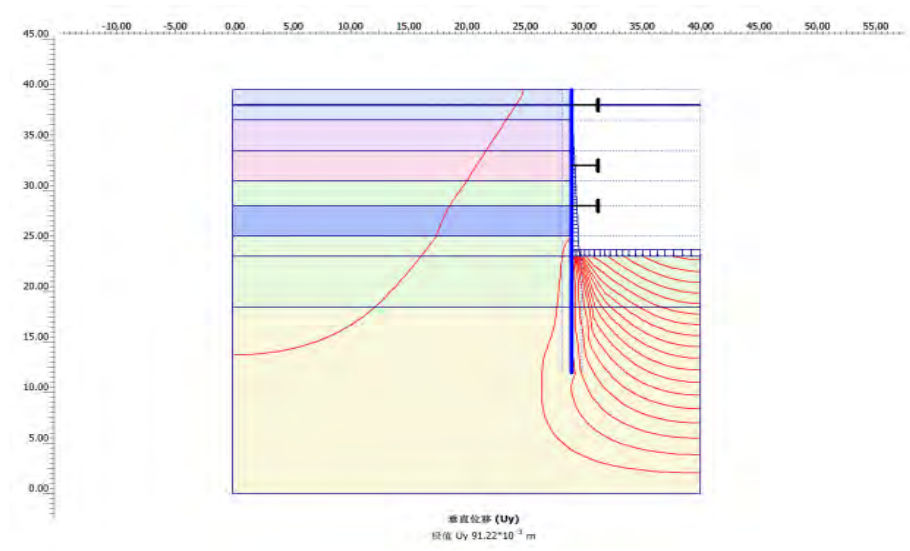

Fig. 3 The Vertical Displacement of Soil (for a depth of excavation of $16.5 \mathrm{~m}$ )

According to Table 2, after excavation, supporting had a significant effect on controlling the deformation of the foundation pit. Due to supporting, the maximum displacement of settlement did not occur after the completion of the excavation of the foundation pit but when the depth of excavation was $3 \mathrm{~m}$. Through comparison between the predicted and measured values, it can be seen that the maximum vertical displacements were consistent, but the measured values of the maximum displacement were generally greater than the predicated values, which was primarily caused by the differences between the simulated and actual soil parameters for the construction site and the disturbance of the construction loads of on-site construction machinery and equipment.

\section{Analysis of Earth Pressure during Step-by-step Excavation}

In the actual engineering design, the boundary between the active zone and the passive zone was not very clear, and the active and passive zones often exchanged. The exchange was related to loading, soil parameters, pile stiffness, and pile-soil contact, etc. According to practical engineering experience and the monitoring results, the active zone above the bottom of the pile was generally stable, while the active and passive zones below the bottom of the pile changed constantly. Therefore, an analysis was carried out of the earth pressure behind the wall (active earth pressure) alone in the following. The results of calculation are shown in Figure 4.

It can be seen from the results of calculation of earth pressure distribution, the active earth pressure behind the wall decreased gradually as the depth of excavation increased and the deformation of the wall increased, and the law of its distribution was approximately triangular. Compared with earth pressure at rest, the decline in the earth pressure at the top of the wall was greater than that in the earth pressure at the bottom of the wall. When the depth of excavation was about $-10.5 \mathrm{~m}$, due to supporting, an inflection point showing the decline in earth pressure occurred 
in the figure showing the results of calculation. Due to supporting, because the flexural deformation of the retaining wall occurred, the deformation at various points of the wall along the direction of the depth of the wall changed like waveforms. An explanation of this phenomenon was that as the depth of excavation increased, the earth pressure behind the wall redistributed under the influence of supporting, namely producing the "soil arching effect".
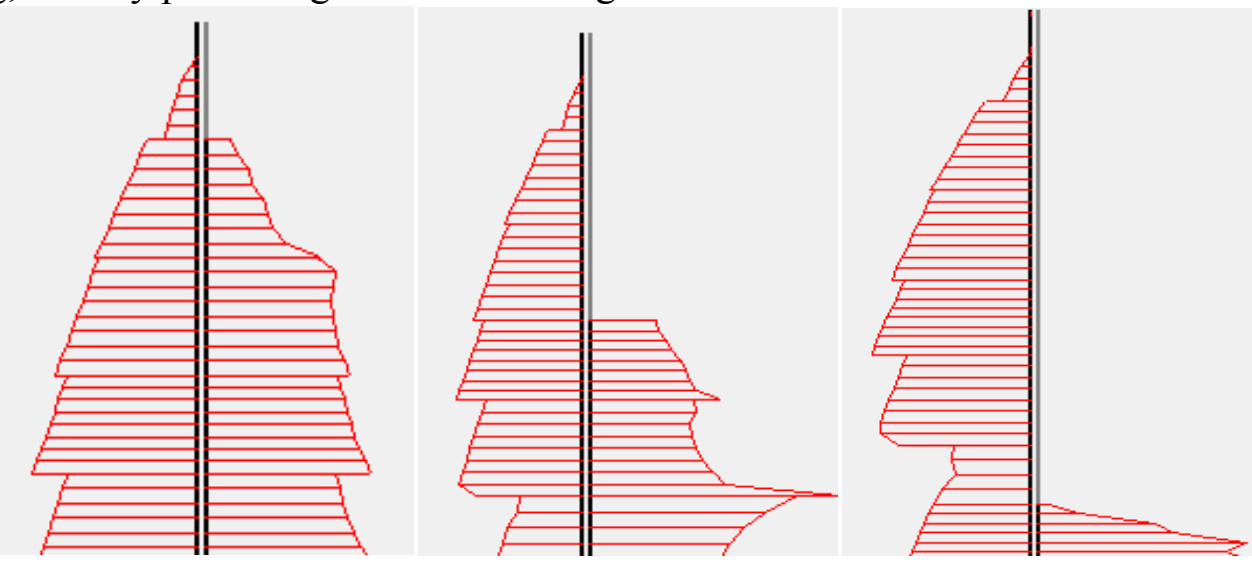

Fig. 4 The Stress Distribution for the Earth Pressure behind the Wall (a depth of excavation of 3, 9, $16.5 \mathrm{~m})$

\section{Conclusion}

Predicting and analyzing the soil deformation and the changes in active earth pressure caused by excavation of super-large foundation pits is not only required for modern metro construction, but also a basis for controlling soil deformation. This paper studied the vertical displacement and deformation of soil during the excavation of a super-large foundation pit, validated the reasonableness of adding supporting and retaining design, and analyzed when and where the foundation pit was the most likely to become unstable during the excavation of the foundation pit, providing reference for construction and design.

\section{Acknowledgement}

This work was financially supported by the Research of Hubei Provincial Department of Education (20121105). (2013230)

\section{References}

[1]Finno R J, Blackbum T J, Roboski J E. Three-dimensional Effects for Supported Excavations in Clay. Journal of Geotechnical and Geoenvironmental Engineering, ASCE, 2007, 133(1):30-36.

[2]Roboski J F. Three-dimensional Performance and Analyses of Deep Excavations [Ph.D. Dissertation]. Evanston: Northwestern University, 2004.

[3]Yang Qingnian. Deformation Characteristics Analyses of Deep Foundation Pits in Wuhan Metro Stations [Ph.D. Dissertation] 2010, 10, 30.

[4]Hou Xueyuan and Yang Min. Design Theory about and Engineering Practice of Deformation Control of Soft Soil Foundations. Shanghai: Tongji University Press.

[5]GUI Guo-qing. Research Actuality and Development Direction on Deep Foundation Engineering [J]. Engineering Mechanics, 2000, 3(Supp): 406-412. 